\title{
TINJAUAN TERHADAP ARBITRASE SYARIAH SEBAGAI ALTERNATIF PENYELESAIAN SENGKETA DI BIDANG PERBANKAN SYARIAH
}

\author{
Andria Luhur Prakoso \\ Fakultas Hukum \\ Universitas Muhammadiyah Surakarta \\ alp120@ums.ac.id
}

\begin{abstract}
Abstrak
$\mathrm{P}$ erkembangan dunia bisnis yang semakin pesat dalam era globalisasi mengakibatkan meningkatnya sengketa yang terjadi diantara pelaku bisnis. Upaya untuk menyelesaikan sengketa tersebut dapat dilakukan melaui dua cara yaitu jalur litigasi dan non litigasi. Undang undang perbankan syariah mengatur juga bahwa penyelesaian sengketa antara pihak bank dan nasabah dapat diselesaikan secara litigasi dan non litigasi. Untuk non litigasi dapat mengunakan model Arbitrase Syariah yang di Indonesia dijalankan oleh BASYARNAS. Tulisan ini akan membahas mengenai bagaimanakah kedudukan dan kewenangan Arbitrase Syariah sebagai lembaga penyelesaian sengketa perbankan syariah serta bagaimanakah kendala dalam pelaksanaan arbitrase syariah di Indonesia. Penelitian ini menggunakan metode penelitian hukum normatif, dengan tujuan untuk memecahkan isu hukum dan memberikan gambaran preskripsi mengenai apa yang seyogyanya. Hasil pembahasan menunjukan bahwa Arbitrase Syariah dalam menyelesaikan sengketa perbankan syariah secara kelembagaan dilakukan oleh BASYARNAS dengan menggunakan prinsip-prinsip syariah yang secara konstitusional berdasarkan Pasal 29 UUD NRI 1945 dan asas kebebasan berkontrak Pasal 1338 Kitab Undang Undang Hukum Perdata dapat dijalankan dan tidak bertentangan dengan hukum positif di Indonesia.Kendala dalam pelaksanaan arbitrase syariah khususnya dalam hal pelaksanaan / eksekusi putusannya karena harus dimohonkan kepada Ketua Pengadilan Negeri setempat dengan adanya kemungkinan untuk ditolak apabila dianggap oleh hakim melanggar ketentuan-ketentuan yang ada pada UUAAPS.
\end{abstract}

Kata Kunci: Arbitrase Syariah, Perbankan Syariah, Penyelesaian Sengketa

\section{Pendahuluan}

Penyelesaian sengketa dalam sistem hukum di Indonesia dapat diselesaikan secara litigasi dan non litigasi. Perkembangan dalam bidang bisnis, para pelaku usaha lebih memilih untuk menyelesaikan sengketa yang timbul diantara mereka dengan pranata penyelesaian sengketa non litigasi. Berbagai hal yang melatarbelakangani kecenderungan tersebut antara lain disebabkan oleh berbagai kelemahan dari pengadilan sebagai penyelenggara pranata litigasi mulai dari lamanya proses, sifat pemeriksaan yang terbuka, dan kemampuan generalis dari para hakim. Sedangkan para pengusaha lebih memilih pranata non litigasi karena cepatnya proses penyelesaian, kompetensi pihak yang berperan sebagai penengah dan lain-lain.

Perkembangan pranata penyelesaian sengketa non litigasi di Indonesia ditandai dengan lahirnya Undang Undang Nomor 30 Tahun 1999 tentang Arbitrase dan Alternatif Penyelesaian Sengketa (UUAAPS) yang didalamnya menjelaskan bahwa penyelesaian sengketa di luar pengadilan dapat diselesaikan dengan cara konsultasi,negosiasi, mediasi, konsolidasi, penilaian ahli, dan Arbitrase.

Penyelesaian secara Arbitrase lebih banyak dibahas dalam undang undang ini sehingga menjadikan undang undang ini sebagai umbrella act aturan tentang arbitrase. Bahwa arbitrase dapat digunakan untuk menyelesaikan sengketa di bidang perdagangan termasuk juga perbankan 
menjadikan lembaga arbitrase semakin berkembang di berbagai sektor termasuk di bidang perbankan syariah. Perkembangan perbankan syariah yang pesat sejak tahun 1999 merupakan hasil dari dukungan regulasi yang memadai yaitu Undang-undang Nomor 10 Tahun 1998 tentang Perubahan Undang-undang Nomor 7 Tahun 1992 dan undang-undang Nomor 23 Tahun 1999 tentang Bank Indonesia yang kemudian diperkuat oleh Undang-undang Nomor 3 Tahun 2004.2 Di tahun 2002, Bank Indonesia memperbaiki aturan tentang unit usaha syariah melalui Peraturan Bank Indonesia Nomor 4/1/PBI Tahun 2002 tentang Perubahan Kegiatan Usaha Bank Umum Konvensional Menjadi Bank Umum Berdasarkan Prinsip Syariah dan Pembukaan Kantor Bank Berdasarkan Prinsip Syariah Oleh Bank Umum Konvensional.3 Terhitung sejak tanggal 16 Juli tahun 2008, industri perbankan syariah Indonesia secara resmi memasuki era baru sehingga Indonesia telah resmi memiliki regulasi perbankan syariah yaitu Undang-undang No. 21 Tahun 2008 tentang Perbankan Syariah.

Pada prinsipnya undang undang perbankan syariah mengatur juga bahwa penyelesaian sengketa antara pihak bank dan nasabah dapat diselesaikan secara litigasi dan non litigasi. Untuk non litigasi dapat mengunakan model Arbitrase namun tentunya dalam teknis pelaksanaannya tidak dapat hanya berpedoman pada UUAAPS tahun 1999 sehingga diperlukan kajian mendalam mengenai konsepsi, prinsip-prinsip, dan juga teknis penerapan arbitrase syariah untuk menyelesaikan sengketa di bidang perbankan syariah.

Berdasarkan latar belakang diatas, maka penulis menfokuskan pembahasan tulisan ini pada dua pokok permasalahan tentang bagaimanakah kedudukan dan kewenangan Arbitrase Syariah sebagai lembaga penyelesaian sengketa perbankan syariah serta bagaimanakah kendala dalam pelaksanaan arbitrase syariah di Indonesia.

\section{Metode Penelitian}

Penelitian ini berdasarkan bidang kajiannya adalah termasuk penelitian hukum normatif, dengan tujuan untuk memecahkan isu hukum dan memberikan gambaran preskripsi mengenai apa yang seyogyanya. Sumber-sumber penelitian yang penulis gunakan dalam penelitian ini berupa : (1) Bahan hukum primer, yaitu peraturan perundang undangan yang mengatur mengenai arbitrase di Indonesia yaitu Undang Undang Nomor 30 Tahun 1999 tentang Arbitrase dan Alternatif Penyelesaian Sengketa, (2) Bahan hukum Sekunder, yaitu bahan hukum yang memberikan penjelasan mengenai bahan hukum primer, (3) Bahan bahan non hukum, yaitu bahan di luar bidang ilmu hukum yang penulis gunakan untuk memperkaya wawasan dan membantu dalam memahami persoalan hukum dalam penelitian ini sepanjang relevan dengan bidang penelitian.

Untuk analisis terhadap hasil penelitian, dalam penelitian ini penulis menggunakan metode pendekaran undang-undang (statutory approach) yaitu melakukan kajian terhadap ketentuan perundangan yang relevan dengan isu yang dibahas.

\section{Pembahasan}

\section{Kedudukan Arbitrase Syariah dalam Sistem Hukum Indonesia}

\section{a. Konsepsi Arbitrase Syariah di Indonesia}

Pengertian Arbitrase menurut Black 's law Dictionary yaitu " Arbitration, a process of dispute resolution in which a neutral third party (arbitrator) renders a decision after a hearing at which both parties have an opportunity to be heard. Where arbitration is voluntary, the disputing parties select the arbitrator who has the power to render a binding decision." "102 Sedangkan Kamus Hukum Ekonomi memberikan pengertian bahwa arbitrase adalah metode penyelesaian sengketa di luar pengadilan dengan memakai jasa wasit atas

102 Henry Campbell Black, Black Law Dictionary, dalam Muhammad Arifin, Arbitrase Syariah sebagai Forum Penyelesaian Sengketa Perbankan Syariah, (Yogyakarta : Pustaka Pelajar, 2016,) 230 
persetujuan para pihak yang bersengketa dan keputusan wasit mempunyai kekuatan hukum mengikat. ${ }^{103}$

Arbitrase dalam studi hukum Islam (fiqh) dikenal dengan istilah tahkim. Secara literal, tahkim berarti mengangkat sebagai wasit atau juru damai sehingga dapat diartikan menjadikan seseorang sebagai penengah suatu sengketa. ${ }^{104}$ Fathurrahman Djamil mengartikan tahkim sebagai pengangkatan seseorang atau lebih sebagai wasit atau juru damai oleh dua orang atau lebih yang bersengketa guna menyelesaikan perkara yang mereka perselisihkan secara damai. ${ }^{105}$

Apabila dikaitkan dan dibungkan dari berbagai perspektif mengenai pengertian diatas dapat ditemukan benang merah keterkaitan antara tahkim dan arbitrase yang merupakan pranata penyelesaian sengketa dengan melibatkan pihak ketiga yang dapat ditunjuk sendiri oleh para pihak.

Selain itu, ditemukan beberapa unsur arbitrase dalam hukum Islam (tahkim) yaitu : ${ }^{106}$ (1) Bahwa cara penyelesaian atau mengakhiri sengketa melalui hakam (arbiter) di luar hakim negara (qadha); (2) Bahwa penunjukan hakam (wasit) dilakukan secara sukarela oleh atau atas persetujuan dan pilihan kedua belah pihak; (3) Bahwa para pihak akan menaati putusan penyelesaian oleh hakam; (4) Penyelesaian sengketa dilakukan dengan penerapan hukum syara'; (5) Tujuan penyelesaian dilakukan dengan cara damai; (6) Putusan yang diberikan hakam bersifat final dan mengikat (final and Binding).

Berbagai unsur diatas semakin menambah keidentikan antara konsep arbitrase dan konsep tahkim yang mana dapat dikategorikan sebagai penyelesaian sengketa di luar pengadilan negara dengan wasit atau pihak ketiga dan sifat putusannya final dan mengikat tanpa adanya upaya hukum lagi.

Arbitrase di Indonesia tunduk pada pedoman-pedoman yang digariskan dalam Undang Undang Nomor 30 tahun 1999 tentang Arbitrase dan Alternatif Penyelesaian Sengketa dimana Pasal 5 UUAAPS menerangkan bahwa sengketa yang dapat diselesaikan hanya sengketa di bidang perdagangan dan terhadapnya dapat diupayakan perdamaian. ${ }^{107}$ Mengenai arbitrase syariah, di Indonesia memang belum ada aturan khusus yang mengatur sehingga secara prinsip juga harus tetap tunduk pada pedoman-pedoman dalam UUAAPS sebagai umbrella act di bidang arbitrase. Untuk kelembagaannya, dalam UUAAPS dapat dibentuk lembaga arbitrase adhoc yang dibentuk khusus untuk penyelesaian perkara-perkara tertentu dan lembaga arbitrase institusional yang sudah eksis terbentuk sehingga secara praktek muncul berbagai jenis lembaga arbitrase yang berkutat khusus di berbagai bidangbidang tertentu misalnya bidang pasar modal, hubungan industrial, lingkungan hidup, dll termasuk juga di bidang syariah. Kesemuanya itu secara normatif tidak melanggar aturan yang ada di UUAAPS.

Arbitrase syariah di Indonesia dapat dikatakan sebagai perkembangan dari tahkim yang telah ada atau dikenal dalam hukum Islam. Keberadaan arbitrase syariah memang hanya dikhususkan untuk penyelesaian sengketa di bidang muamalah yang dilakukan secara syariah. Sehingga arbitrase syariah hanya menangani dan menyelesaikan sengketa

103 A.F. Elly erawaty dan J.S.Badudu, Kamus Hukum Ekonomi, (Jakarta : Proyek ELIPS, 1996), 5

104 Mardani, Hukum Ekonomi Syariah di Indonesia, (Bandung : Refika Aditama, 2011), 98

105 Fathurrahman Djamil, Arbitrase dalam Perspektif Sejarah Islam, dalam Satria Effendi M.Zein,et.al, Arbitrase Islam di Indonesia, (Jakarta : Badan Arbitrase Muamalat Indonesia, 1994), 31

106 Muhammad Arifin, Arbitrase Syariah, 231

107 Pasal 5 UUAAPS menyatakan :(1) Sengketa yang dapat diselesaikan melalui arbitrase hanya sengketa di bidang perdagangan dan mengenai hak yang menurut hukum dan peraturan perundang-undangan dikuasai sepenuhnya oleh pihak yang bersengketa. (2) Sengketa yang tidak dapat diselesaikan melalui arbitrase adalah sengketa yang menurut peraturan perundang-undangan tidak dapat diadakan perdamaian. 
yang muncul atas akad ${ }^{108}$ yang dibuat berdasarkan prinsip-prinsip syariah. Meskipun sifatnya hanya sektoral, arbitrase syariah tetap merupakan bagian dari arbitrase nasional di Indonesia.

\section{b. Prinsip Syariah dalam hukum positif Indonesia}

Hukum yang berlaku di Indonesia untuk mengatur masalah keperdataan sampai saat ini bersifat pluralisme dalam arti ada tiga sumber hukum yang berlaku dan dapat dipilih oleh penduduk Indonesia yaitu Hukum Adat, Hukum Islam, dan Hukum kodifikasi peninggalan Belanda. Hukum Adat tumbuh dan berkembang seiring dengan adanya peradapan dan menjadi sumber hukum tertua yang tumbuh di masyarakat, Hukum Islam tumbuh seiring dengan persebaran agama Islam di Indonesia dan ada pendapat yang menyatakan bahwa ketika seseorang yang memeluk agama Islam maka secara prinsip juga mengakui keberadaan dan keberlakuan hukum Islam. Sedangkan hukum peninggalan Belanda tumbuh seiring kolonialisme dan beberapa aturan masih diterapkan untuk mencegah adanya kekosongan hukum di Indonesia.

Eksistensi hukum Islam dalam sistem hukum nasional dapat teraktualisasi dalam empat bentuk yaitu : ${ }^{109}$ (1) Sebagai bagian integral dari hukum nasional; (2) Diakui kemandirian, kekuatan, dan wibawanya oleh hukum nasional dan diberi status sebagai hukum nasional; (3) Berfungsi sebagai penyaring bagi materi hukum nasional; (4) Menjadi bahan dan unsur utama bagi pembentukan hukum nasional.

Menurut Hazairin ${ }^{110}$, keberadaan hukum Islam secara konstitusional diakui dalam Konstitusi Indonesia yaitu ketentuan Pasal 29 UUD NRI $1945^{111}$ yang merupakan penjabaran normatif dari Sila Kesatu Pancasila. Sehingga untuk penduduk Indonesia yang beragama Islam ketentuan ini memberi kebebasan untuk beribadah dan negara harus memperhatikan keberlakuan hukum Islam bagi pemeluknya melalui peraturan perundang-undangan serta melindungi penganut agama Islam dari hal-hal yang bertentangan dengan prinsip syariah bagi umat Islam.

Berkaitan dengan perkembangan kegiatan ekonomi syariah saat ini maka ada dua kecenderungan perkembangan hukum Islam di Indonesia yaitu : ${ }^{112}$ (1) Hukum Islam mengalami pergeseran orientasi yang fokus kepada persoalan ibadah (hablum minallah) bergeser menjadi persoalan muamalah ( hablum minannas); (2) Perkembangan dari Hukum Islam itu sendiri yang awalnya dalam perdebatan hukum hanya mengacu pada mazhab yang dipegang selama ini yakni mazhab Syafi'i, dalam perkembangannya juga telah menjadikan mazhab lain seperti Hanafiyah, Malikiyah, Hambaliyah bahkan pikiranpikiran diluar mazhab tersebut yang masih dianggap sejalan dan tidak bertentangan dengan prinsip Islam

Untuk kegiatan ekonomi syariah termasuk di dalamnya perbankan dan kegiatan muamalah lainnya seperti perdagangan, sebagian memerlukan campur tangan atau kekuasaan negara untuk mengatur meskipun sebagian juga tidak. Sedangkan untuk

108 Istilah akad dalam bahasa arab disebut sebagai "perjanjian" dalam hukum positif Indonesia. Syamsul Anwar menyebut bahwa akad sebagai pertemuan ijab kabul sebagai pernyataan kehendak dua pihak atau lebih untuk melahirkan suatu akibat hukum. Syamsul Anwar, Hukum Perjanjian Syariah : Studi tentang Teori Akad dalam Fiqh Muamalah, (Jakarta : PT Rajagrafindo Persada, 2007), 68.

109 Abdul Halim Barkatullah dan Teguh Prasetyo, Hukum Islam Menjawab Tantangan Zaman yang Terus Berkembang, (Yogyakarta : Pustaka Pelajar, 2006), 71

110 Hazairin, Demokrasi Pancasila, (Jakarta : Rineka Cipta, 1990), 33 -34

111 Pasal 29 UUD NRI 1945 ayat (1) Negara berdasar atas Ketuhanan Yang Maha Esa, (2) Negara menjamin kemerdekaan tiap-tiap penduduk untuk memeluk agamanya masing-masing dan untuk beribadat menurut agama dan kepercayaannya itu.

112 Sudirman Tebba, Perkembangan Mutakhir Hukum Islam di Asia Tenggara : Studi Kasus Hukum Keluarga dan Pengkodifikasiannya, (Bandung : Mizan, 1993), 15 
kegiatan ibadah antara manusia dan Tuhan secara vertikal tidak memerlukan campur tangan kekuasaan negara. ${ }^{113}$

Kitab Undang Undang Hukum Perdata sebagai lex generalis dalam kaitan dengan peraturan di bidang keperdataan memberi peluang kepada setiap penduduk Indonesia untuk memilih atau menundukkan diri baik dalam aturan hukum adat, hukum kolonial Belanda, maupun hukum Islam meskipun yang bersangkutan penganut agama Islam ataupun bukan. Termasuk juga dalam lalu lintas kegiatan di bidang perbankan syariah. Asas kebebasan berkontrak yang berlaku berdasarkan Pasal $1338^{114}$ Kitab Undang Undang Hukum Perdata menjadi dasar dapat dijalankannya arbitrase syariah sebagai salah satu alternatif penyelesaian sengketa di bidang perbankan syariah. Sehingga secara konstitusional berdasarkan Pasal 29 UUD NRI 1945 maka prinsip syariah dapat dijalankan di Indonesia dan juga berdasarkan pada asas kebebasan berkontrak Pasal 1338 Kitab Undang Undang Hukum Perdata.

\section{c. Kedudukan dan Kewenangan Arbitrase Syariah dalam Penyelesaian Sengketa Perbankan Syariah}

Secara umum, aturan pokok mengenai arbitrase terdapat dalam Undang Undang Nomor 30 Tahun 1999 tentang Arbitrase dan Alternatif Penyelesaian Sengketa (UUAAPS). Undang undang tersebut lahir didasarkan pada Undang Undang Nomor 14 Tahun 1970 tentang Ketentuan Ketentuan Pokok Kekuasaan Kehakiman yang kemudian diubah dengan Undang Undang Nomor 35 tahun 1999. Pasal 3 Undang Undang Kekuasaan Kehakiman Tahun 1970 menyebutkan "Penyelesaian perkara di luar pengadilan,atas dasar perdamaian atau melalui wasit (arbitrase), tetap diperbolehkan." Selanjutnya wujud formal dari ketentuan pasal itu diwujudkan melalui UUAAPS. Perkembangan undang undang tentang kekuasaan kehakiman sampai dengan saat ini melalui Undang Undang Nomor 48 Tahun 2009 tentang Kekuasaan Kehakiman ${ }^{115}$ pun tetap mengakui lembaga penyelesaian sengketa di luar pengadilan (salah satunya arbitrase) bahkan lebih rinci dibanding undang undang kekuasaan kehakiman sebelumnya. Keberadaan UUAAPS menjadi penting sebagai umbrella act untuk keberadaan arbitrase di Indonesia, termasuk arbitrase syariah.

UUAAPS menjadi pedoman dalam pelaksaanaan penyelesaian sengketa secara arbitrase di Indonesia, baik lembaga arbitrase adhoc yang baru dibentuk ketika ada permasalahan maupun lembaga arbitrase konstitusional yang telah eksis seperti BANI dan BASYARNAS. Pasal 3 UUAAPS ${ }^{116}$ secara tegas menjelaskan mengenai kompetensi absolut yang dimiliki oleh pranata arbitrase ini. Sehingga apabila para pihak yang terlibat sengketa di bidang perdata termasuk perbankan syariah dan para pihak tersebut telah bersepakat untuk menyelesaikan sengketa yang terjadi diantara mereka melalui arbitrase maka Pengadilan Negeri ataupun Pengadilan Agama menjadi tidak lagi wenang untuk memeriksa apabila memutus sengketa tersebut.

113 Rifyal Ka’bah, Hukum Islam di Indonesia, (Jakata : Universitas Yarsi, 1999), 56

114 Pasal 1338 KUHPerdata menyatakan : "Semua persetujuan yang dibuat sesuai dengan undang-undang berlaku sebagai undang-undang bagi mereka yang membuatnya. Persetujuan itu tidak dapat ditarik kembali selain dengan kesepakatan kedua belah pihak, atau karena alasan-alasan yang ditentukan oleh undangundang. Persetujuan harus dilaksanakan dengan itikad baik."

115 Pasal 38 ayat(1) UU No. 48 Tahun 2009 tentang Kekuasaan Kehakiman menyatakan “(1) Selain Mahkamah Agung dan badan peradilan di bawahnya serta Mahkamah Konstitusi, terdapat badan badan lain yang fungsinya berkaitan dengan kekuasan kehakiman. (2) Fungsi yang berkaitan dengan kekuasaan kehakiman sebagaimana dimaksud pada ayat (1) meliputi: a. penyelidikan dan penyidikan; b. penuntutan; c. pelaksanaan putusan; d. pemberian jasa hukum; dan e. penyelesaian sengketa di luar pengadilan. (3) Ketentuan mengenai badan-badan lain yang fungsinya berkaitan dengan kekuasaan kehakiman diatur dalam undang-undang.

116 Pasal 3 UUAAPS menyatakan : "Pengadilan Negeri tidak berwenang untuk mengadili sengketa para pihak yang telah terikat dalam perjanjian arbitrase." 
Perjanjian Arbitrase ${ }^{117}$ yang dimaksud Pasal 3 UUAAPS baik yang berupa Pactum de Compromitendo maupun Acta Compromis harus dibuat secara tertulis oleh para pihak yang terlibat dalam kontrak bisnis tersebut. Dalam kaitannya dengan penyelesaian sengketa di bidang perbankan syariah maka apabila dalam akad yang dibuat antara nasabah dan pihak bank di dalamnya ada klausul yang menyatakan bahwa apabila terjadi perselisihan maka memilih arbitrase syariah sebagai lembaga penyelesainya maka pengadilan agama tidak lagi berwenang untuk mengadili.

Selanjutnya regulasi di bidang perbankan syariah yaitu UU Nomor 21 Tahun 2008 tentang Perbankan Syariah juga memberikan legalitas terhadap pelaksanaan arbitrase sebagai alternatif penyelesaian sengketa jika terjadi perselisihan antara nasabah dengan pihak bank. Pasal 55 Undang Undang Perbankan Syariah ${ }^{118}$ menerangkan bahwa sengketa di lingkungan perbankan syariah dapat diselesaikan melalui pengadilan dalam lingkungan peradilan agama atau dapat dilakukan dengan mekanisme lain dicantumkan secara tegas dalam akad dengan catatan tidak boleh bertentangan dengan prinsip syariah. Jadi arbitrase syariah berwenang dan bahkan memiliki kompetensi absolut dalam menyelesaikan sengketa di perbankan syariah apabila para pihak yang terlibat menyatakan kesepakatan secara tertulis dan tegas untuk menggunakan arbitrase dalam akad yang mengikat para pihak tersebut.

\section{d. Kelembagaan Arbitrase Syariah di Indonesia}

Padatahun 1993 dibentukBadanArbitrase MuamalatIndonesia(BAMUI)yang sekarang bernama BASYARNAS (Badan Arbitrase Syariah Nasional) sebagai salah satu upaya untuk melakukan penyelesaian sengketa di bidang mu'amalat khususnya perekonomian syariah. Berdirinya BAMUI ini dimaksudkan sebagai antisipasi terhadap permasalahan hukum yang mungkin timbul akibat penerapan hukum mu'amalah oleh lembaga keuangan syariah yang pada waktu itu telah berdiri. Kemudian selain berpedoman pada UUAAPS, validitas arbitrase syariah juga diperkukuh melalui Fatwa DSN-MUI (Dewan Syariah Nasional - Majelis Ulama Indonesia). Pendirian BASYARNAS merupakan bentuk hakam yang dilembagakan secara permanen. Sebagai lembaga permanen, BASYARNAS memiliki peraturan prosedur yang dijadikan pedoman beracara untuk menyelesaikan sengketa yang diputus. Sesuai keputusan MUI nomor Kep.09/MUI/XII/2003, BASYARNAS merupakan lembaga hakam (arbitrase syariah) satu-satunya di Indonesia yang merupakan perangkat organisasi MUI yang pengurusnya diangkat dan diberhentikan oleh MUI namun demikian dalam menjalankan tugasnya BASYARNAS tetap bersifat otonom dan independen. ${ }^{119}$

Keberadaan BASYARNAS di Indonesia semakin mempertegas pengakuan prinsip syariah dalam dalam sistem hukum Indonesia. BASYARNAS yang ada saat ini merupakan lembaga arbitrase institusional yang sah berdasarkan payung hukum arbitrase yaitu UUAAPS 1999 yang berimplikasi terhadap kemajuan hukum Islam di Indonesia dalam artian para pihak yang menginginkan putusan atas suatu sengketa ataupun pendapat mengikat (binding opinion) dari sebuah lembaga arbitrase nasional yang sah dapat memilih BASYARNAS sebagai lembaganya.

117 Pasal 1 ayat 3 UUAAPS "Perjanjian arbitrase adalah suatu kesepakatan berupa klausula arbitrase yang tercantum dalam suatu perjanjian tertulis yang dibuat para pihak sebelum timbul sengketa, atau suatu perjanjian arbitrase tersendiri yang dibuat para pihak setelah timbul sengketa."

118 Pasal 55 UU Perbankan Syariah menyebutkan ; (1)Penyelesaian sengketa Perbankan Syariah dilakukan oleh pengadilan dalam lingkungan Peradilan Agama. (2) Dalam hal para pihak telah memperjanjikan penyelesaian sengketa selain sebagaimana dimaksud pada ayat (1), penyelesaian sengketa dilakukan sesuai dengan isi Akad. (3) Penyelesaian sengketa sebagaimana dimaksud pada ayat (2) tidak boleh bertentangan dengan Prinsip Syariah.

119 Muhammad Arifin, Arbitrase Syariah 315 


\section{Kendala dalam Pelaksanaan Arbitrase Syariah di Indonesia}

Pelaksanaan arbitrase syariah di Indonesia secara prinsip dilakasanakan oleh BASYARNAS sebagai satu-satunya lembaga arbitrase institusional yang menyelesaikan sengketa di bidang ekonomi syariah. Berkaitan dengan kendala dalam pelaksanaan arbitrase syariah dalam tulisan ini akan dibahas mengenai kendala dalam hal pelaksanaan putusan arbitrase syariah. Sebagai lembaga penyelesaian sengketa, pada dasarnya arbitrase dapat disejajarkan dengan lembaga peradilan karena putusan yang dihasilkan sifatnya final dan mengikat. Namun salah satu kelemahan mendasar dari arbitrase adalah tidak memiliki alat kelengkapan sendiri untuk melakukan eksekusi atas putusan yang dihasilkan sehingga untuk dapat melakukan eksekusi terhadap putusan arbiter diperlukan campur tangan pengadilan negeri.

Secara umum pedoman yang ada pada UUAAPS menyatakan apabila ternyata tidak ada itikad baik dari salah salah pihak untuk menjalankan putusan arbitrase dengan sukarela maka diperlukan upaya paksa. Untuk dapat dilaksanakan secara paksa maka putusan arbitrase tersebut harus dideponir ${ }^{120}$ dalam akta pendaftaran di kepaniteraan pengadilan negeri dalam jangka waktu selambat-lambatnya 30 hari setelah putusan diucapkan dan apabila lewat jangka waktu ini maka menyebabkan putusan tidak dapat dimohonkan penetapan eksekusi. ${ }^{121}$ Selanjutnya sesuai ketentuan Pasal 61 jo. Pasal 61 ayat (1) UUAAPS dijelaskan apabila dalam jangka waktu 30 hari setelah pencatatan dalam akta pendaftaran di kepaniteraan pengadilan negeri ternyata belum dilaksanakan secara sukarela oleh para pihak maka salah satu pihak dapat mengajukan permohonan kepada Ketua Pengadilan Negeri untuk mengeluarkan perintah pelaksanaan eksekusi secara paksa sesuai ketentuan pelaksanaan putusan dalam perkara perdata yang telah mempunyai kekuatan hukum tetap. Sebagaimana diketahui bahwa putusan arbitrase bersifat mandiri, final, dan mengikat maka Ketua Pengadilan Negeri tidak berwenang untuk memeriksa alasan atas pertimbangan dari putusan arbitrase nasional tetapi kewenangan Ketua Pengadilan Negeri terbatas pada pemeriksaan secara formal dan terbatas pada ketentuan Pasal 62 ayat (2) UUAAPS. ${ }^{122}$ Kemudian terhadap putusan Ketua Pengadilan Negeri yang menolak mengeluarkan penetapan eksekusi diatas maka tidak terbuka upaya hukum apapun.

Di bidang hukum syariah,dengan diamandemennya Undang-Undang No. 7 Tahun 1989 dengan Undang-Undang No. 3 Tahun 2006 memberikan perluasan kewenangan kepada Pengadilan Agama. Di samping berwenang memeriksa, memutus dan menyelesaikan sengketa di tingkat pertama antara orang-orang yang beragama Islam di bidang perkawaninan, waris, wasiat, hibah, wakaf, zakat, infak, dan shadaqah. Pengadilan Agama juga berwenang untuk

120 Rahmadi Usman,Op. Cit, hlm. 185 menjelaskan bahwa tindakan deponir tersebut berupa penyerahan lembar asli atau salinan otentik dari putusan kemudian dilakukan pencatatan dan penandatanganan bersama pada bagian akhir atau di pinggir putusan oleh panitera pengadilan negeri dan arbiter atau kuasanya kemudian catatan tersebut adalah sah sebagai akta pendaftaran putusan arbitrase nasional.

121 Lihat ketentuan Pasal 59 ayat (1) dan (4) UUAAPS

122 Pasal 62 ayat (2) UUAAPS menyatakan Ketua Pengadilan Negeri sebagaimana dimaksud dalam ayat (1) sebelum memberikan perintah pelaksanaan, memeriksa terlebih dahulu apakah putusan arbitrase memenuhi ketentuan Pasal 4 dan Pasal 5, serta tidak bertentangan dengan kesusilaan dan ketertiban umum. Lihat juga ketentuan Pasal 4 dan 5 UUAAPS sebagai berikut : Pasal 4 ayat (1) Dalam hal para pihak telah menyetujui bahwa sengketa di antara mereka akan diselesaikan melalui arbitrase dan para pihak telah memberikan wewenang, maka arbiter berwenang menentukan dalam putusannya mengenai hak dan kewajiban para pihak jika hal ini tidak diatur dalam perjanjian mereka.(2) Persetujuan untuk menyelesaikan sengketa melalui arbitrase sebagaimana dimaksud dalam ayat (1) dimuat dalam suatu dokumen yang ditandatangani oleh para pihak.(3) Dalam hal disepakati penyelesaian sengketa melalui arbitrase terjadi dalam bentuk pertukaran surat, maka pengiriman teleks, telegram, faksimili, e-mail atau dalam bentuk sarana komunikasi lainnya, wajib disertai dengan suatu catatan penerimaan oleh para pihak. Pasal 5 ayat (1) Sengketa yang dapat diselesaikan melalui arbitrase hanya sengketa di bidang perdagangan dan mengenai hak yang menurut hukum dan peraturan perundang-undangan dikuasai sepenuhnya oleh pihak yang bersengketa. (2) Sengketa yang tidak dapat diselesaikan melalui arbitrase adalah sengketa yang menurut peraturan perundang-undangan tidak dapat diadakan perdamaian. 
memeriksa, memutus, dan menyelesaikan sengketa di bidang ekonomi syariah. ${ }^{123}$ Kewenangan Pengadilan Agama ini juga diperkuat dengan putusan Mahkamah Konstitusi atas perkara No. 93/PUU-X/2012 yang menghapuskan penjelasan Pasal 55 ayat (2) Undang-Undang No. 21 Tahun 2008 tentang Perbankan Syariah, sehingga menjadikan Pengadilan Agama satu-satunya lembaga Peradilan yang berwenang untuk menyelesaikan sengketa ekonomi syariah.

Terkait dengan kompetensi pengadilan mana yang berwenang untuk mengabulkan permohonan untuk eksekusi putusan arbitrase, Mahkamah Agung telah mengeluarkan Surat Edaran No. 08 Tahun 2008 tentang Eksekusi Putusan Badan Arbitrase Syariah. Angka 4 surat edaran ini secara tegas menyatakan bahwa dalam hal putusan Badan Arbitrase Syariah tidak dilaksanakan secara sukarela, maka berdasarkan permohonan salah satu pihak yang bersengketa, Ketua Pengadilan Agamalah yang berwenang memerintakan pelaksanaan putusan Badan Arbitrase Syariah. Sayangnya, berlakunya SEMA ini tidak bertahan lama. Dengan direvisinya Undang-Undang No. 4 Tahun 2004 dengan Undang-Undang No. 48 Tahun 2009 tentang Kekuasaan Kehakiman, Pasal 59 UU ini dalam penjelasannya secara jelas menyatakan bahwa eksekusi putusan arbitrase, termasuk arbitrase syariah, dilaksanakan berdasarkan perintah Ketua Pengadilan Umum. Kemudian berdasarkan Pasal 59 Undang-Undang No. 48 Tahun 2009 tentang Kekuasaan Kehakiman ini, bulan Mei 2010, Mahkamah Agung mengeluarkan SEMA No. 8 Tahun 2010 tentang Penegasan Tidak Berlakunya Surat Edaran Mahkamah Agung Nomor 08 Tahun 2008 tentang Eksekusi Putusan Arbitrase Syariah. Sehingga meskipun secara yuridis untuk sengketa ekonomi syariah saat ini sudah menjadi kompetensi absolut dari Pengadilan Agama namun untuk permohonan eksekusi terhadap putusan arbitrase syariah tetap harus dimohonkan kepada Pengadilan Negeri.

Ketua Pengadilan Negeri berpedoman pada Pasal 62 UUAAPS dalam mempertimbangkan apakah mengabulkan permohonan atas putusan arbitrase tersebut atau tidak. Terhadap putusan arbitrase nasional yang ditolak permohonannya maka tidak terbuka upaya hukum apapun sehingga putusan arbitrase hanya semacam kemenangan diatas kertas saja. Campur tangan pengadilan dalam penentuan dikabulkan atau tidaknya permohonan eksekusi ini seakan menempatkan posisi lembaga arbitrase sebagai lembaga alternatif penyelesaian sengketa non litigasi berada di bawah lembaga litigasi/ pengadilan.

\section{Kesimpulan}

Arbitrase syariah sebagai bentuk khusus dari Arbitrase yang berlaku di Indonesia secara umum tetap berpedoman pada Undang Undang Nomor 30 Tahun 1999 tentang Arbitrase dan Alternatif Penyelesaian Sengketa. Arbitrase Syariah dalam menyeleksaikan sengketa perbankan syariah secara kelembagaan dilakukan oleh BASYARNAS dengan menggunakan prinsip-prinsip syariah yang secara konstitusional berdasarkan Pasal 29 UUD NRI 1945 dan asas kebebasan berkontrak Pasal 1338 Kitab Undang Undang Hukum Perdata dapat dijalankan dan tidak bertentangan dengan hukum positif di Indonesia.

Kendala dalam pelaksanaan arbitrase syariah khususnya dalam hal pelaksanaan / eksekusi putusannya karena harus dimohonkan kepada Ketua Pengadilan Negeri setempat dengan adanya kemungkinan untuk ditolak apabila dianggap oleh hakim melanggar ketentuan-ketentuan yang ada pada UUAAPS. Secara kelembagaan, campur tangan pengadilan dalam eksekusi putusan arbitrase syariah seakan menempatkan posisi arbitrase syariah di bawah pengadilan negeri.

123 Pasal 49 UU No. 3 Tahun 2006 : "Pengadilan agama bertugas dan berwenang memeriksa, memutus, dan menyelesaikan perkara di tingkat pertama antara orang-orang yang beragama Islam di bidang: a. perkawinan; b. waris; c. wasiat; d. hibah; e. wakaf; f. zakat; g. infaq; h. shadaqah; dan i. ekonomi syari'ah." 


\section{Daftar Pustaka}

Anwar, Syamsul 2007. Hukum Perjanjian Syariah : Studi tentang Teori Akad dalam Fiqh Muamalah. Jakarta : PT Rajagrafindo Persada.

Arifin, Muhammad .2016. Arbitrase Syariah sebagai Forum Penyelesaian Sengketa Perbankan Syariah. Yogyakarta : Pustaka Pelajar.

Barkatullah, Abdul Halim dan Teguh Prasetyo. 2006. Hukum Islam Menjawab Tantangan Zaman yang Terus Berkembang. Yogyakarta : Pustaka Pelajar.

Erawaty, A.F. Elly dan J.S.Badudu. 1996. Kamus Hukum Ekonomi. Jakarta : Proyek ELIPS.

Hazairin. 1990. Demokrasi Pancasila. Jakarta : Rineka Cipta.

Ka’bah, Rifyal .1999. Hukum Islam di Indonesia. Jakarta : Universitas Yarsi.

M.Zein, Satria Effendi. et.al. 1994. Arbitrase Islam di Indonesia. Jakarta : Badan Arbitrase Muamalat Indonesia.

Mardani. 2011. Hukum Ekonomi Syariah di Indonesia. Bandung : Refika Aditama.

Tebba, Sudirman. 1993. Perkembangan Mutakhir Hukum Islam di Asia Tenggara : Studi Kasus Hukum Keluarga dan Pengkodifikasiannya. Bandung : Mizan.

Usman, Rahmadi. 2013. Pilihan Penyelesaian Sengketa di Luar Pengadilan. Bandung : PT Citra Aditya Bakti.

Peraturan Perundang-Undangan

Undang Undang Dasar Negara Republik Indonesia Tahun 1945

Kitab Undang Undang Hukum Perdata

Undang Undang Nomor 30 Tahun 1999 tentang Arbitrase dan Alternatif Penyelesaian Sengketa

Undang Undang Nomor 21 Tahun 2008 tentang Perbankan Syariah 